\title{
Imágenes en divertículos del tubo digestivo: Localizacio- nes infrecuentes. Serie de casos
}

Carolina Whittle $P^{1}$, Giancarlo Schiappacasse $F^{1}$, Ema Leal $M^{2}$, Gerhard Franz G $^{2}$, Daniel Hasson $A^{2}$, Ignacio Maldonado $S^{3}$, Claudio Cortes $A^{3}$.

1.Profesor asociado de Radiología. Facultad de Medicina Clínica Alemana - Universidad del Desarrollo. Departamento Imágenes. Clínica Alemana de Santiago de Chile. Santiago - Chile.

2. Residente Radiología. Facultad de Medicina, Clínica Alemana-Universidad del Desarrollo. Santiago - Chile.

3.Médico Radiólogo. Departamento de Imágenes, Clínica Alemana de Santiago de Chile. Santiago - Chile.

\section{Imaging in infrequent digestive diverticula. Case series}

\begin{abstract}
Diverticula may occur in any segment of the digestive tract: esophagus, stomach, duodenum, jejunum, ileum, appendix, and colon. Its clinical manifestations are nonspecific which may turn difficult an early diagnosis, leading to a higher risk of complications. We present a cases serie of atypical digestive diverticula and to describe the findings on the different imaging techniques. We performed a retrospective review on the imaging computer archives of our institution. The atypical diverticula were selected. Zenker and Killian-Jamieson's diverticulums in esophagus. In stomach ocasionally gastric diverticula. Diverticula in small intestine have a low prevalence, the most common location is duodenum. Colonic diverticula may present a atypical location or presentation. The appendicular and Meckel diverticuli are uncommon. The digestive diverticula are uncommon, except the colonic ones. The radiologist must be familiar with it's different locations in order to be able to recognize it and diagnose it properly

Keywords: Digestive diverticula, diverticulitis, digestive imaging, gastro intestinal diverticula, esophageal diverticulum
\end{abstract}

Resumen. Los diverticulos se pueden localizar en todo el tubo digestivo (TD): esófago, estómago, duodeno, yeyuno, íleon, apéndice, colon. Son infrecuentes, salvo en colon. Sus manifestaciones clínicas son inespecíficas, con difícil diagnóstico y mayor riesgo de complicaciones. Se presenta una serie de divertículos digestivos atípicos, mostrando las características imagenológicas multimodalidad y describir los hallazgos claves.

Es una revisión retrospectiva en el archivo computacional de nuestra institución. Selección de casos de divertículos de presentación inhabitual por sus características, localización u origen. En esófago los divertículos de Zenker y Killian-Jamieson. En estómago los divertículos gástricos infrecuentes. Los divertículos en intestino delgado tienen baja prevalencia, el más frecuente en duodeno. Los divertículos colónicos pueden tener una localización o presentación atípica. Los divertículos apendiculares y Meckel presentan baja prevalencia.

Los divertículos digestivos son infrecuentes, excepto los colónicos. El radiólogo debe estar familiarizado con las diferentes ubicaciones de ellos, para reconocerlos y poder diagnosticarlos.

Palabras claves: Divertículo digestivo, diverticulitis, imágenes digestivas, divertículo gastrointestinal, divertículo esofágico.

Whittle $C$, et al. Imágenes en divertículos del tubo digestivo: Localizaciones infrecuentes. Serie de casos. Rev Chil Radiol 2018; 24(2): 67-78.

Correspondencia: Carolina Whittle / cwhittle@alemana.cl

Trabajo enviado el 04 de abril de 2018. Aceptado para publicación el 14 de junio de 2018.

\section{Introducción}

Los divertículos son un hallazgo frecuente en los exámenes por imagen, pudiendo presentarse en todo el tubo digestivo: esófago, estómago, intestino delgado: duodeno, yeyuno, íleon, apéndice, colon', con una prevalencia variable según cada segmento. Corresponden a salientes de perfil en vísceras 
huecas, usualmente con herniación de la mucosa y submucosa a través de algún defecto de la pared del $a a^{2}$. Sus manifestaciones clínicas son inespecíficas lo que dificulta el diagnostico precoz y determina un mayor riesgo de complicaciones asociadas.

Los divertículos son frecuentes en el colon y tienen una baja frecuencia en el resto del tubo digestivo².

Si bien originalmente fueron descritos en estudios fluoroscópicos, es posible identificarlos en prácticamente todas las modalidades diagnósticas disponibles a la fecha, siendo muchas veces diagnosticables de manera incidental en estudios no relacionados, por lo que es importante que el radiólogo general se familiarice con estos.

\section{Objetivos}

Los objetivos de nuestro trabajo son: presentar una serie de casos de divertículos del tubo digestivo en localizaciones atípicas y realizar una revisión de la literatura. Evaluar las características epidemiológicas, clínicas y pronosticas más relevantes. Mostrar las características imagenológicas multimodalidad que orientan al diagnóstico y describir los hallazgos claves para el diagnóstico.

\section{Material y método}

Se realizó una revisión retrospectiva en el archivo computacional del servicio de imágenes de nuestra institución. Se seleccionaron aquellos casos de divertículos del tubo digestivo de presentación poco habitual por sus características, localización u origen.

\section{Revisión de casos y discusión Divertículos esofágicos}

Los divertículos esofágicos son infrecuentes, con una prevalencia de $0,04-0,06 \%^{3}$, observándose en aproximadamente el $5 \%$ de los estudios por disfagia ${ }^{4} y$ se observan con mayor frecuencia en adultos mayores.
Estos pueden ser congénitos o adquiridos y corresponden a evaginaciones de la pared esofágica que comunican con el lumen principal ${ }^{3,5,6,7}$.

Al momento de diferenciar los distintos tipos de divertículos esofágicos, el enfoque más práctico es dividir el esófago en sus porciones superior, media e inferior. En la porción superior pueden encontrarse los divertículos de Zenker y de Killian-Jamieson ${ }^{8}$; En el esófago medio pueden verse pequeños divertículos epibronquiales por tracción y pulsión; y en el esófago distal divertículos epifrénicos.

En esófago superior se identifica con frecuencia el divertículo de Zenker, con una prevalencia estimada de $0,05 \%{ }^{3}$. Los divertículos laterales de la faringe son muy raros, siendo el más conocido el «divertículo de Killian-Jamieson» ${ }^{3,5,6}$ (Figura 1).

El divertículo de Zenker, es un divertículo cricofaríngeo o faringo-esofágico. Corresponde a una protrusión de la mucosa faríngea a través de una zona de debilidad de la pared posterior de la faringe (triángulo de Killian), localizado entre el músculo constrictor inferior y el músculo cricofaríngeo, por encima del esfínter esofágico superior ${ }^{3,5,7}$.

Fisiopatológicamente la teoría más aceptada sobre el origen de este divertículo, consiste en anomalías motoras de la deglución, con descoordinación de la contracción de los músculos faríngeos y el esfínter esofágico inferior, lo que llevaría a un aumento de presión sobre la pared faríngea posterior, produciendo una herniación a nivel del triángulo de Killian a través de su punto más débili,6,9.

Este corresponde a un pseudodiverticulo, ya que solo compromete la mucosa y submucosa. Su prevalencia es mayor en pacientes añosos, ocurriendo el $80 \%$ entre los $60-80$ años.

El método de elección para su diagnóstico es el trago de bario con imágenes dinámicas mediante fluoroscopía 4 . En estas se observa una saliente "saculación"

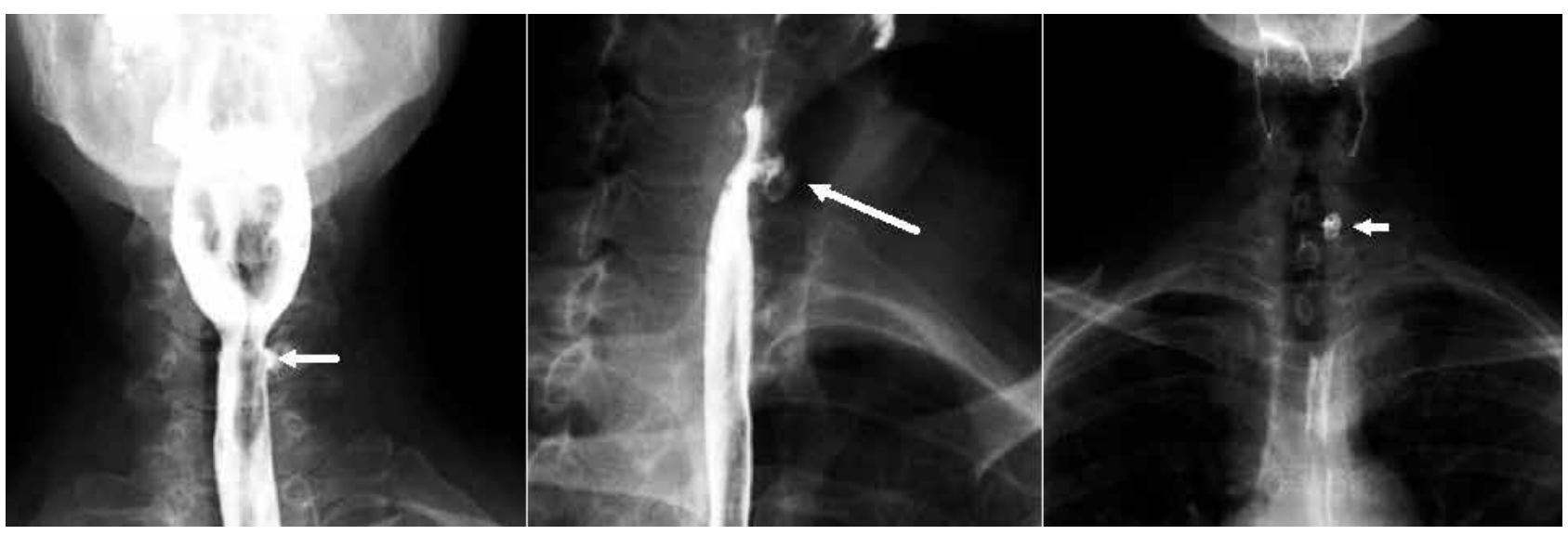

Figura 1. Divertículo de Killian-Jamieson. Esofagograma baritado que demuestra un divertículo lateral izquierdo a la unión faringo-esofágica (flecha blanca). 
de la línea media posterior de la faringe, cerca de la unión faringo esofágica. La mejor proyección para su evaluación es la lateral inmediatamente después de la deglución, usualmente a nivel de C5-C6 ${ }^{9}$.

Los síntomas más frecuentes son halitosis, disfagia y broncoaspiración, pero pueden ser asintomáticos. Cuando son lo suficientemente grandes pueden actuar como reservorio alimentario, siendo causa de regurgitación alimentaria, incluso varias horas después de su ingestión. También puede ser una causa de aspiración recurrente en pacientes añosos y con daño neurológico ${ }^{10}$.

Los divertículos de Killian-Jamieson son herniaciones de la mucosa en la pared antero-lateral del esófago cervical, por debajo del músculo cricofaríngeo, los que protruyen a través de las fibras musculares del esófago, inmediatamente por debajo de su inserción en el cartílago cricoides. Suelen ser de menor tamaño que los de Zenker ${ }^{3,7,8,11}$. Ocurren con mayor frecuencia en el lado izquierdo, pero pueden ser bilaterales. Su incidencia es de entre $0,02 \%$ a $0,025 \%$ de la población, cuatro veces menos frecuente que el divertículo de Zenker ${ }^{8,12}$.

El cuadro clínico es variable y rara vez son sintomáticos, pero pueden manifestarse como halitosis, disfagia, dificultad para tragar, regurgitación y tos. En casos muy extremos, pueden alcanzar un tamaño suficiente como para comprimir el nervio laríngeo recurrente, produciendo ronquera; o comprimir el esófago y producir afagia, o incluso romperse hacia un bronquio, 6,711 (Figuras 2, 3 y 4).

En el esófago medio pueden existir divertículos por tracción y por pulsión. Los primeros ocurren como consecuencia de cicatrices, adherencias y tejido fibroso en el tórax, los que traccionarían gradualmente el esófago produciendo estos divertículos. En el pasado las principales causas eran secuelas de tuberculosis y enfermedades granulomatosas, siendo infrecuentes en la actualidad.

Los divertículos por pulsión son pequeñas saculaciones causados por puntos de debilidad en la pared del esófago, en los que protruye la mucosa a través de la capa muscular. En general estos divertículos son pequeños y no requieren manejo específico.

En el esófago inferior, los divertículos epifrénicos se consideran típicamente como divertículos de pulsión y ocurren secundariamente a descoordinación entre la motilidad del esófago y el esfínter esofágico inferior, como ocurre en acalasia, lo que explica la alta asociación entre ambas patologías ${ }^{13}$. Usualmente asintomáticos y se encuentran incidentalmente en estudios por disfagia 0 acalasia.

Los estudios baritados son el método de elección para el diagnóstico de todos los divertículos esofági$\cos ^{8}$. Si bien también son visibles en endoscopía, su sensibilidad es menor cuando su orificio de apertura es pequeño. Esto es especialmente cierto para los
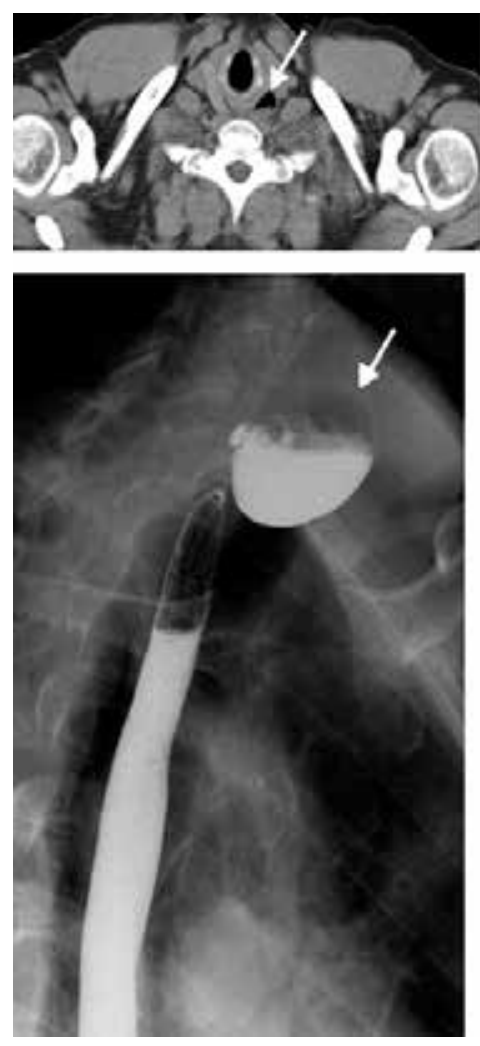
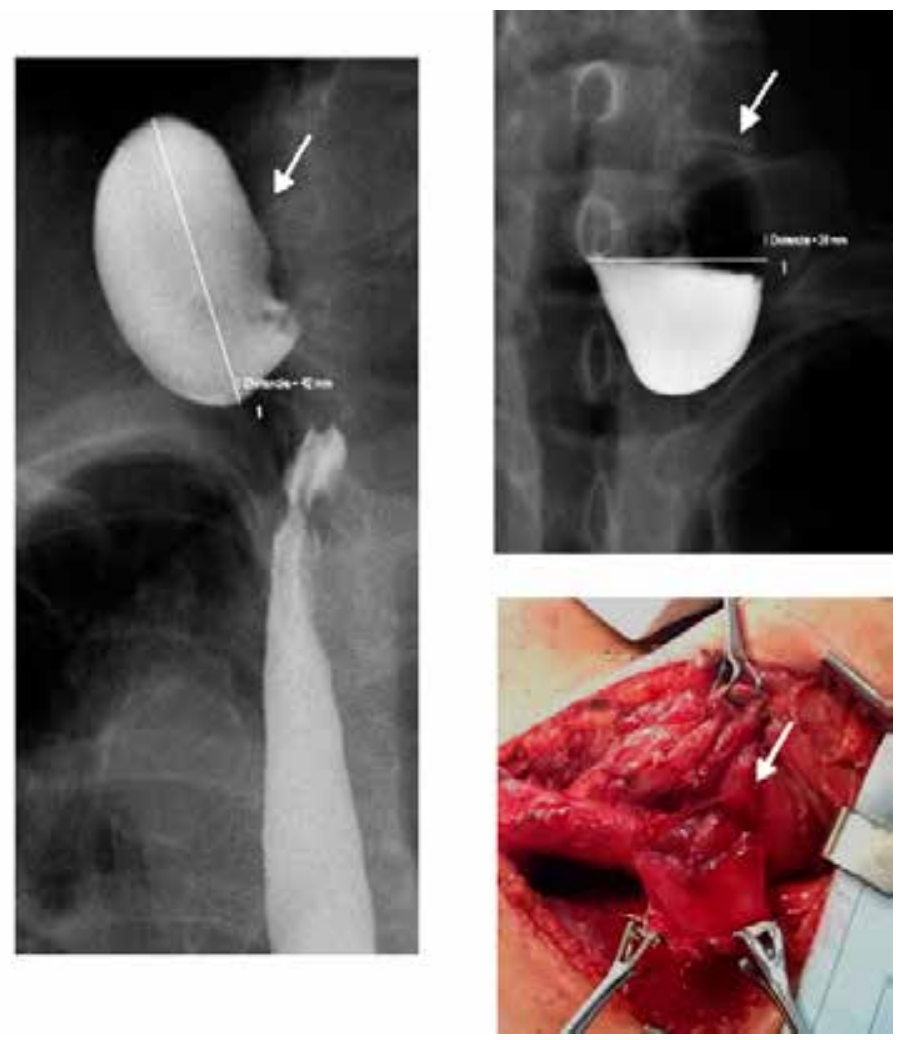

Figura 2. Divertículo de Zenker. En imágenes de tomografía computada (flecha blanca) radiografía EED (flecha blanca) y cirugía (flecha blanca) que demuestran gran divertículo sobre el esfínter esofágico superior en un paciente de 43 años. 

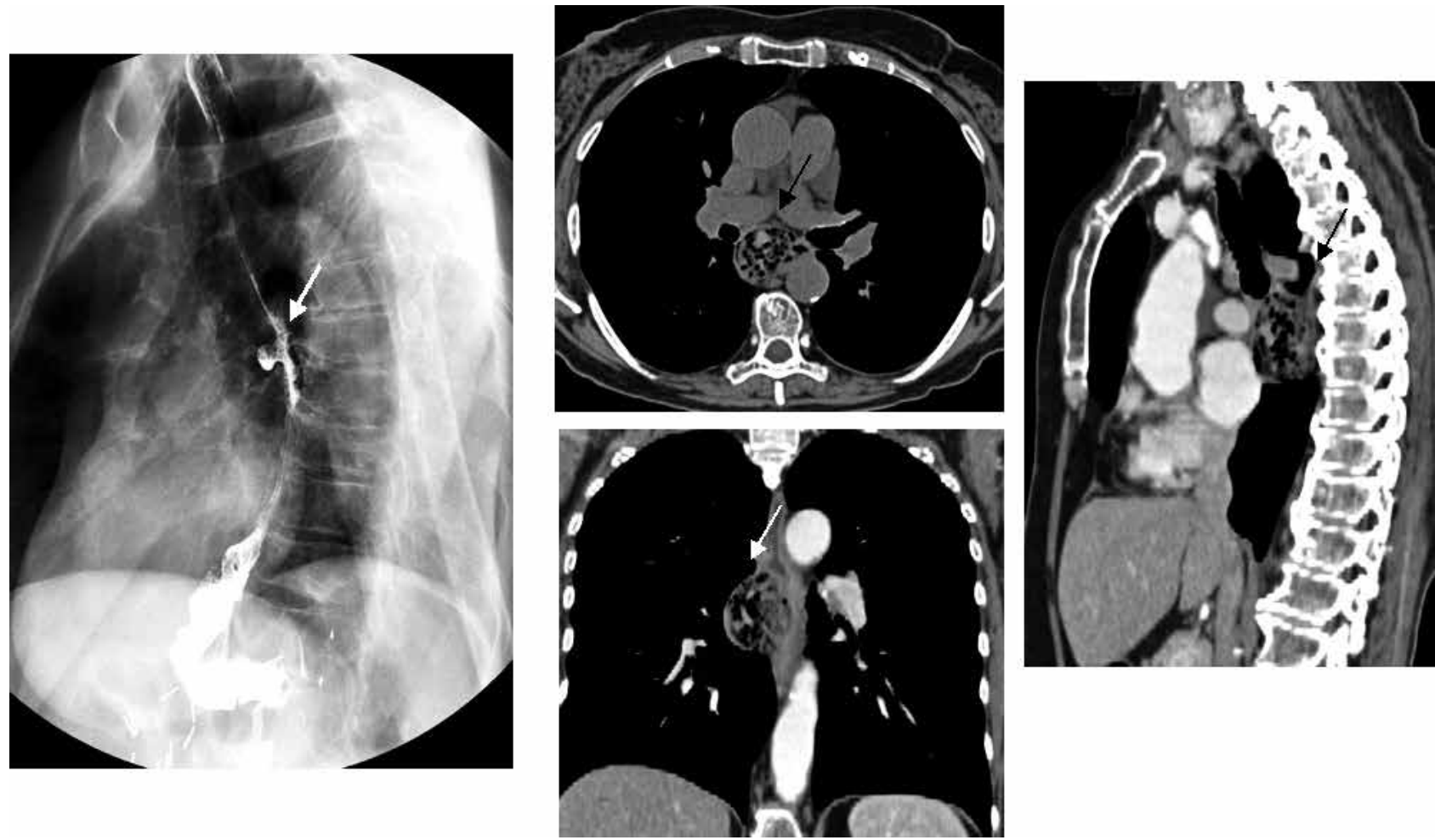

Figura 3. Divertículo en esófago medio. Imágenes de radiografía EED (flecha blanca) y tomografía computada de tórax (flechas blancas y negras), que evidencian divertículo esofágico en tercio medio.
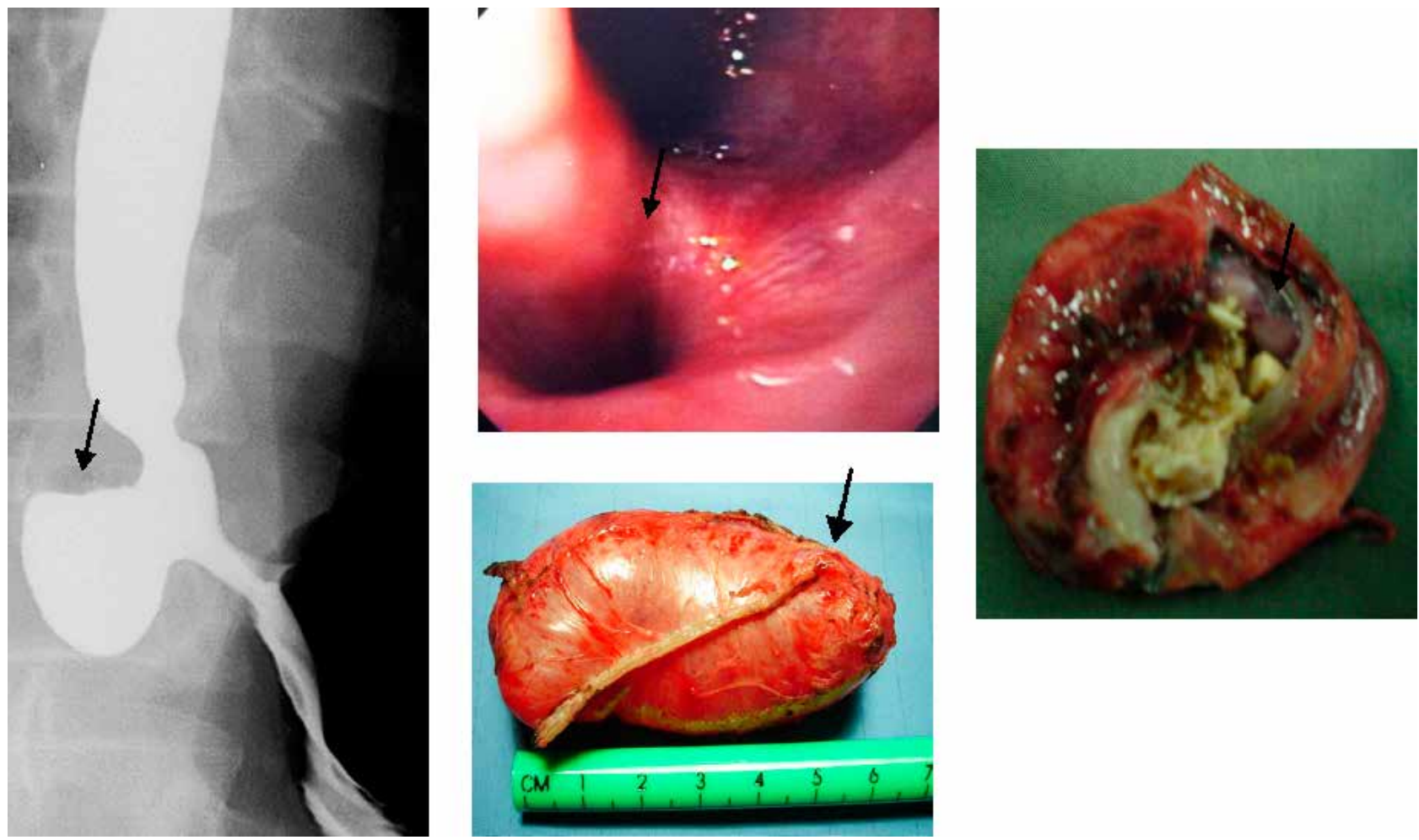

Figura 4. Divertículo de esófago medio. Imágenes Rx EED (flecha negra) endoscopía esofágica (flecha negra) y piezas operatorias (flechas negras), que muestran un gran divertículo esofágico. 
divertículos de Zenker, ya que se ubican por sobre el esfínter esofágico superior, región donde el endoscopio tiene visibilidad limitada, existiendo incluso el riesgo de introducir el endoscopio en el divertículo, con riesgo de perforación de éste ${ }^{13}$.

La mayoría de los divertículos esofágicos son asintomáticos y no requieren tratamiento. En casos severos pueden ser sintomáticos, en ellos se puede intentar manejo quirúrgico o endoscópico. Para el divertículo de Zenker sintomático el tratamiento es usualmente la resección ${ }^{10}$, acompañada de miotomia cricofaringea para disminuir la presión del esfínter y evitar su recidiva. Los divertículos del esófago medio y epifrénicos rara vez requieren tratamiento ${ }^{14}$. Se han descrito como complicaciones tardías de los divertículos de Zenker canceres escamosos, perforación de estos y sangrado digestivo alto, sin embargo, son muy infrecuentes ${ }^{13}$.

\section{Divertículos Gástricos}

Los divertículos gástricos son raros, con una tasa de detección mediante endoscopía entre un 0,01\% y $0,11 \%{ }^{1,15}$. Pueden ser congénitos o adquiridos. El $75 \%$ de los congénitos se ubica en la pared posterior del fondo gástrico ${ }^{15}$, mientras que los divertículos adquiridos ocurren más frecuentemente en el antro y se asocian a otras patologías como ulceras pépticas u obstrucción del vaciamiento gástrico.

Usualmente son asintomáticos o tienen sintomatología vaga como dolor, náuseas, disfagia, entre otros ${ }^{1}$.

En general son un hallazgo en exámenes de imagen o endoscopia en pacientes asintomáticos y no requieren tratamiento específico.

Sus complicaciones son poco frecuentes e incluyen ulcera, perforación, torsión y hemorragia ${ }^{16}$. En las imágenes baritadas por fluoroscopía se observa como una saliente de perfil de la pared gástrica. En tomografía computada se puede observar como una saculación bien definida de la pared, la que puede contener fluido o gas, lo que demuestra comunicación con la cavidad gástrica ${ }^{17}$.

El manejo quirúrgico se reserva para aquellos divertículos que son de gran tamaño, sintomáticos o aquellos complicados ${ }^{15}$ (Figuras 5, 6 y 7 ).

\section{Divertículos en intestino delgado}

Son una entidad poco frecuente, con una prevalencia estimada entre 0,06 y $5 \%$ en estudios de autopsias ${ }^{18,19}$. El $79 \%$ de ellos se localizan en el duodeno, $18 \%$ en el yeyuno o íleon y en 3\% existen divertículos en dos o más segmentos ${ }^{20}$.

Los divertículos duodenales son los más frecuentes y se ubican adyacentes a la papila de Vater ${ }^{20}$, con prevalencias reportadas de $2-5 \%$ de los pacientes en estudios baritados, $7 \%$ de los pacientes sometidos a colangiopancreatografía endoscópica retrograda y en el $7 \%$ de las tomografías computadas ${ }^{21}$. La gran mayoría de los divertículos duodenales son extraluminales y se postula que son adquiridos como resultado de un defecto en el punto de entrada de los vasos sanguíneos a este nivel ${ }^{22}$.

Los divertículos en yeyuno e íleon también son
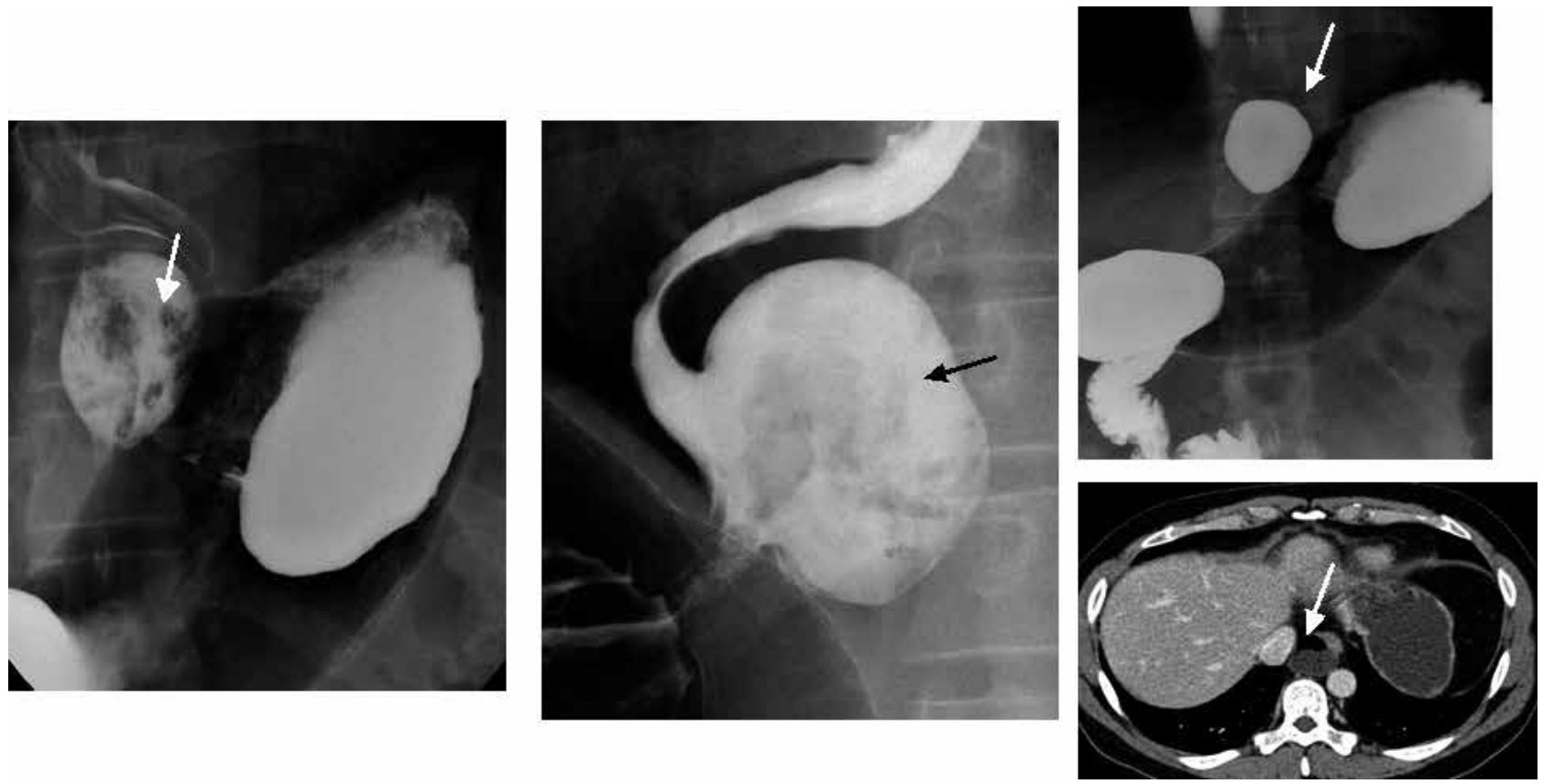

Figura 5. Divertículos en esófago inferior. Imágenes radiografía EED (flechas blancas y negras) e imagen axial de tomografía computada de abdomen con contraste endovenoso (flecha blanca), en las que se identifica un divertículo epifrénico sin signos de complicación. 

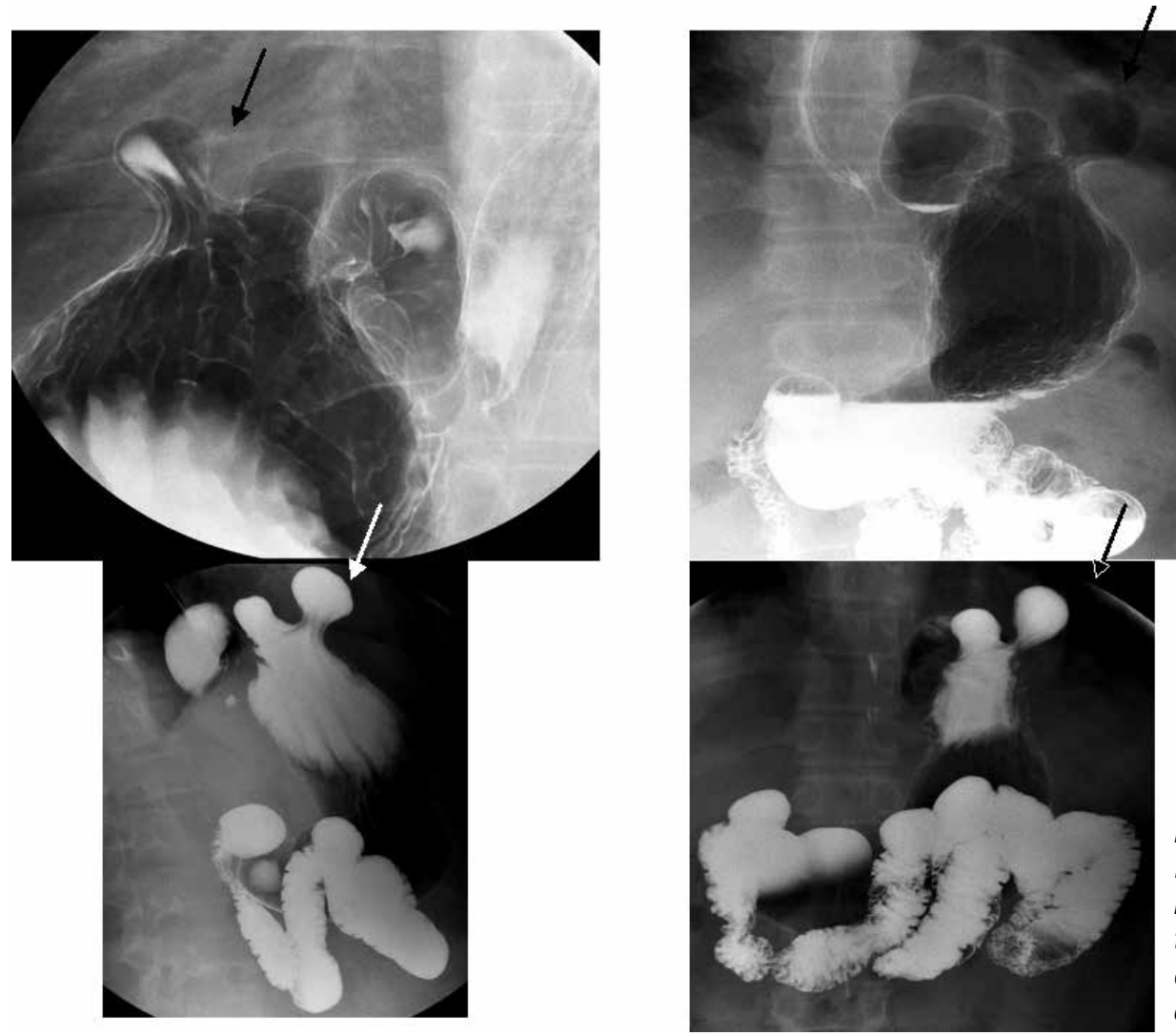

Figura 6. Divertículos en estómago. Imágenes radiografía EED (flechas negras y blanca) que muestran tres divertículos en el fondo del estómago, sin signos de complicación.
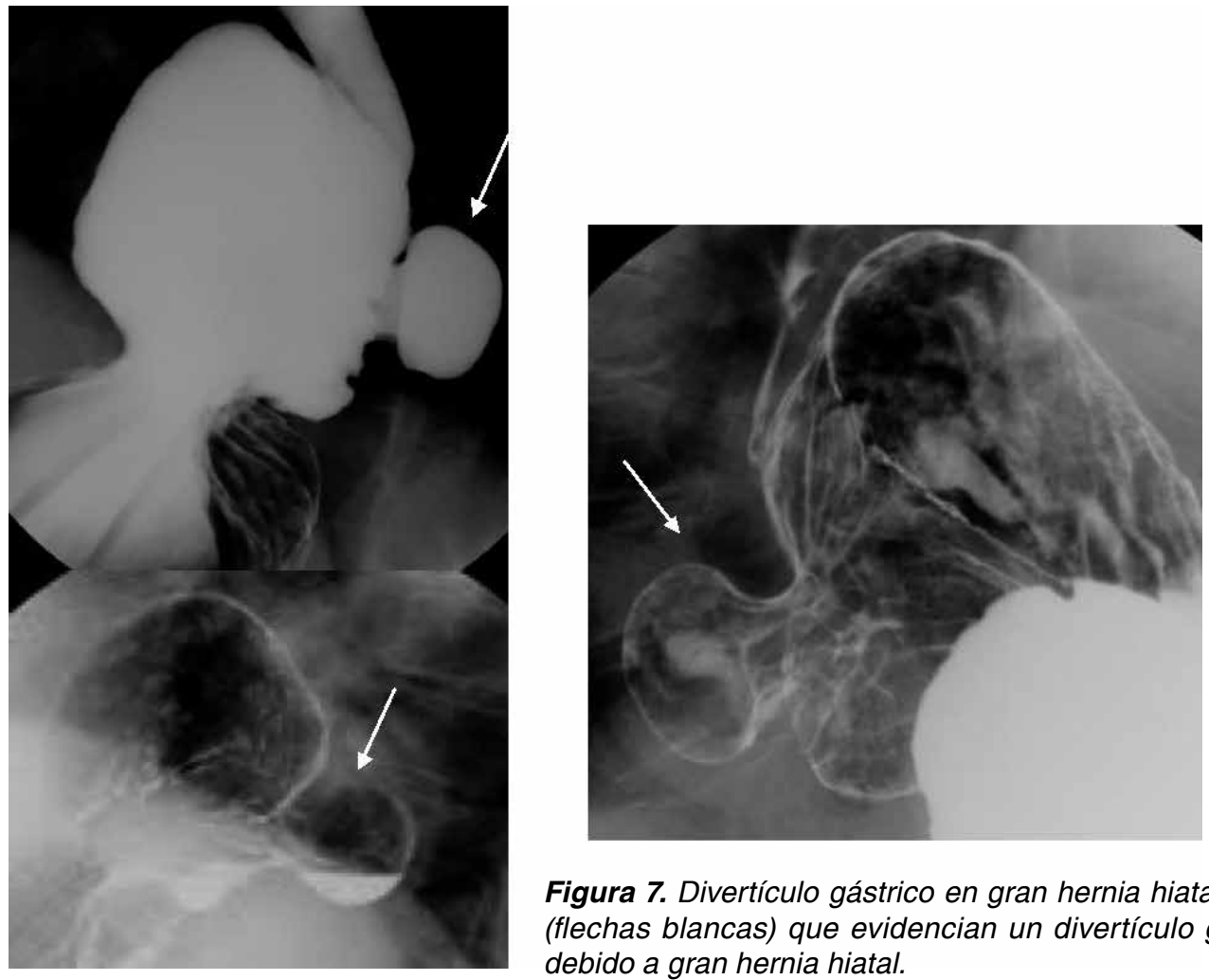

Figura 7. Divertículo gástrico en gran hernia hiatal. Imágenes radiografía EED (flechas blancas) que evidencian un divertículo gástrico en cavidad torácica debido a gran hernia hiatal. 
inhabituales, con una incidencia en la literatura que varía entre 0,6 a $2,3 \%^{23}$. Estos en su mayoría están ubicados en la porción proximal del yeyuno. Con frecuencia se asocian a desordenes de la motilidad intestinal con aumento de la presión intraluminal, como esclerosis sistémica progresiva, neuropatías y miopatías ${ }^{24}$.

La diverticulitis de intestino delgado clínicamente puede ser inespecífica y ser difícil de distinguir de otras causas de dolor abdominal.

Para los divertículos duodenales los síntomas más comunes son dolores cólicos epigástricos postprandiales y vómitos secundarios a obstrucción duodenal parcial o intermitente. Debido a la íntima relación entre estos divertículos y la papila mayor se ha descrito formación de cálculos biliares in situ y obstrucción de la vía biliar distal ${ }^{21}$.

La acumulación de contenido alimentario en los divertículos de intestino delgado puede llevar a sobrecrecimiento bacteriano, que puede causar secundariamente problemas de absorción, meteorismo, discomfort abdominal y diarrea o esteatorrea.

Se ha reportado este tipo de síntomas hasta en el $40 \%$ de los pacientes con divertículos yeyuno-ileales ${ }^{25}$.

Los divertículos duodenales son un hallazgo frecuente en estudios de tomografía computada y se observan como saculaciones con contenido aéreo o líquido en la segunda porción del duodeno adyacente a la ampolla de Vater. También son claramente demostrados en los estudios baritados como una saculación de la pared del duodeno ${ }^{26}$. Los divertículos de intestino yeyuno-ileales se pueden observar en estudios baritados, tomografía computada o enteroresonancia como defectos globulares que sobrepasan el contorno de la pared intestinal ${ }^{23}$.

El manejo consiste en observación en casos asintomáticos y manejo activo en los casos sintomáticos. En los casos de síntomas malabsortivos se puede intentar un manejo inicial con antibióticos. La cirugía se reserva para los casos complicados ${ }^{27}$ (Figuras 8, 9 y 10).

\section{Divertículo de Meckel}

Es la anomalía congénita más común del tracto gastrointestinal y corresponde a un subtipo especial de divertículo del intestino delgado ${ }^{28}$. Resulta de la obliteración incompleta del ducto vitelino en la vida fetal, llevando a la formación de un divertículo verdadero del intestino delgado en su borde antimesentérico. Representa un remanente del ducto onfalomesentérico $^{28}$. El divertículo de Meckel tiene una prevalencia estimada de $2 \%$ y se ubican usualmente a $40-100 \mathrm{~cm}$
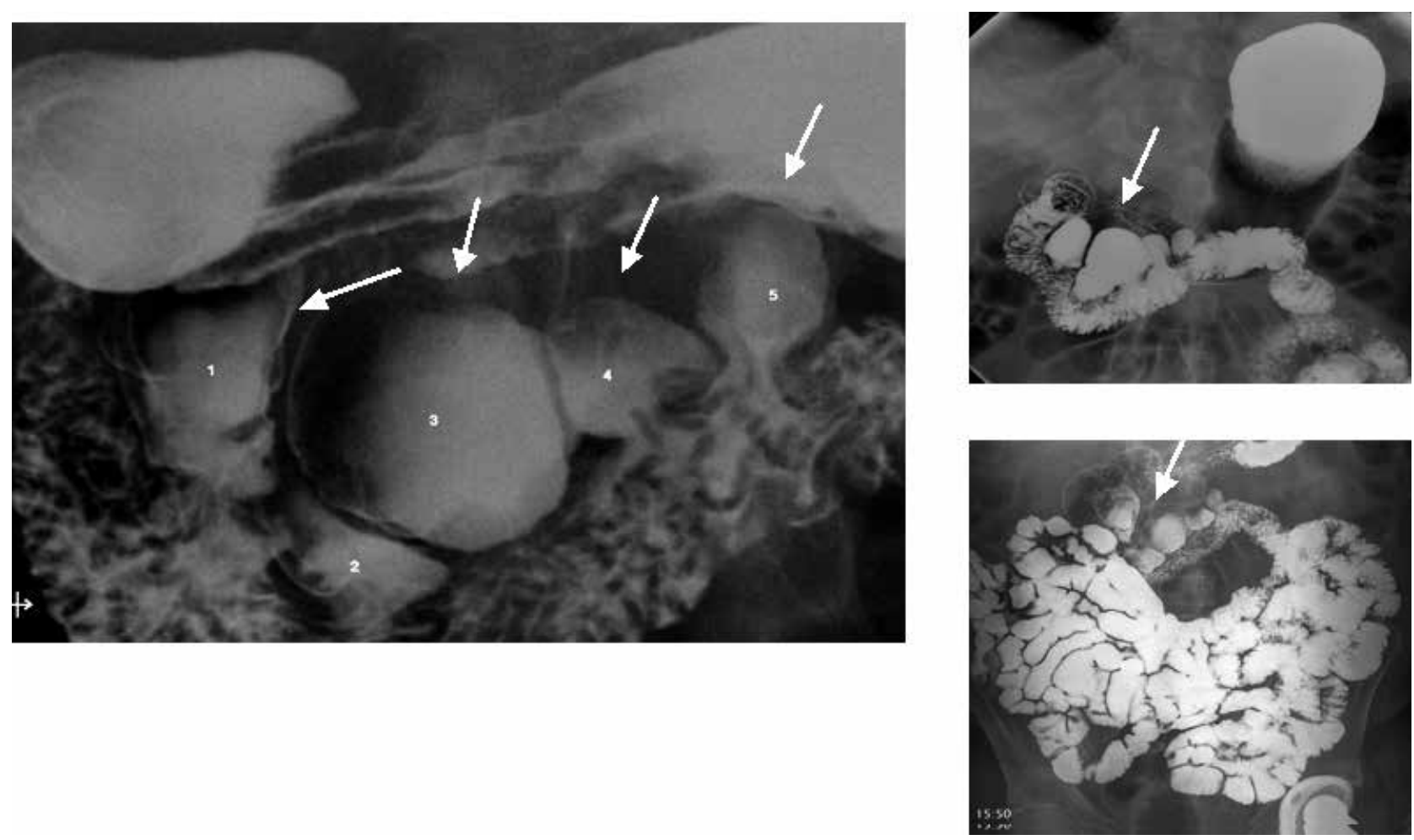

Figura 8. Divertículos duodenales. Imágenes de Radiografía EED y tránsito intestinal, en las que se visualiza grandes divertículos a este nivel (flechas blancas). 

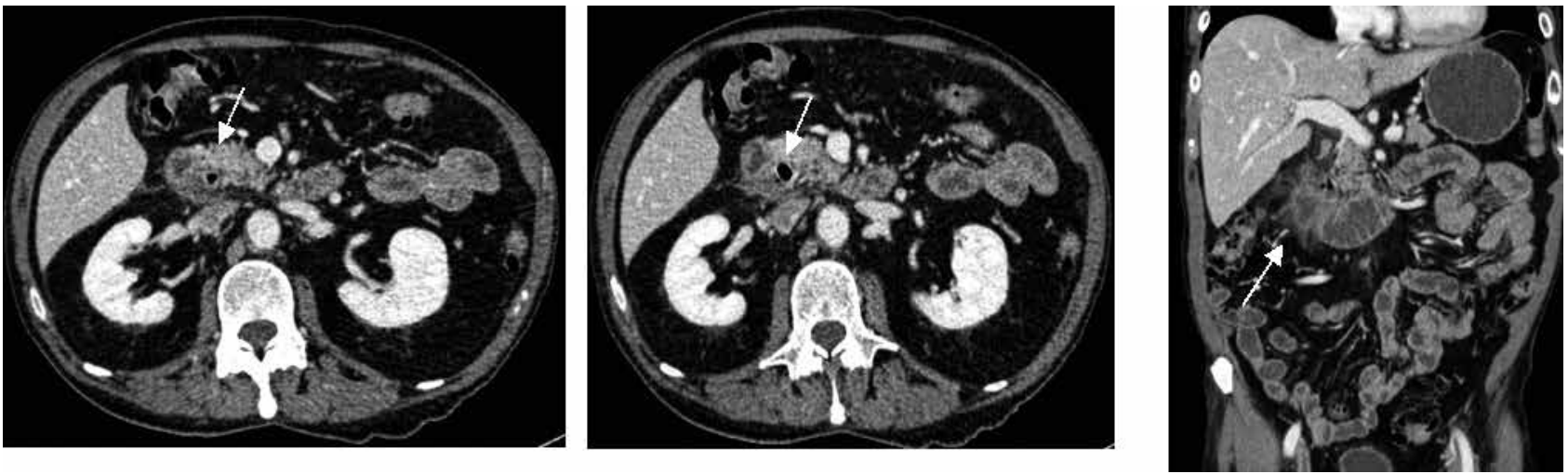

Figura 9. Diverticulitis Duodenal. Imágenes de tomografía computada de abdomen con contraste endovenoso en corte axial y reconstrucción en el plano coronal que evidencian diverticulitis duodenal de la unión de la segunda con la tercera porción, no se observan colecciones ni perforación en el duodeno (flechas blancas).
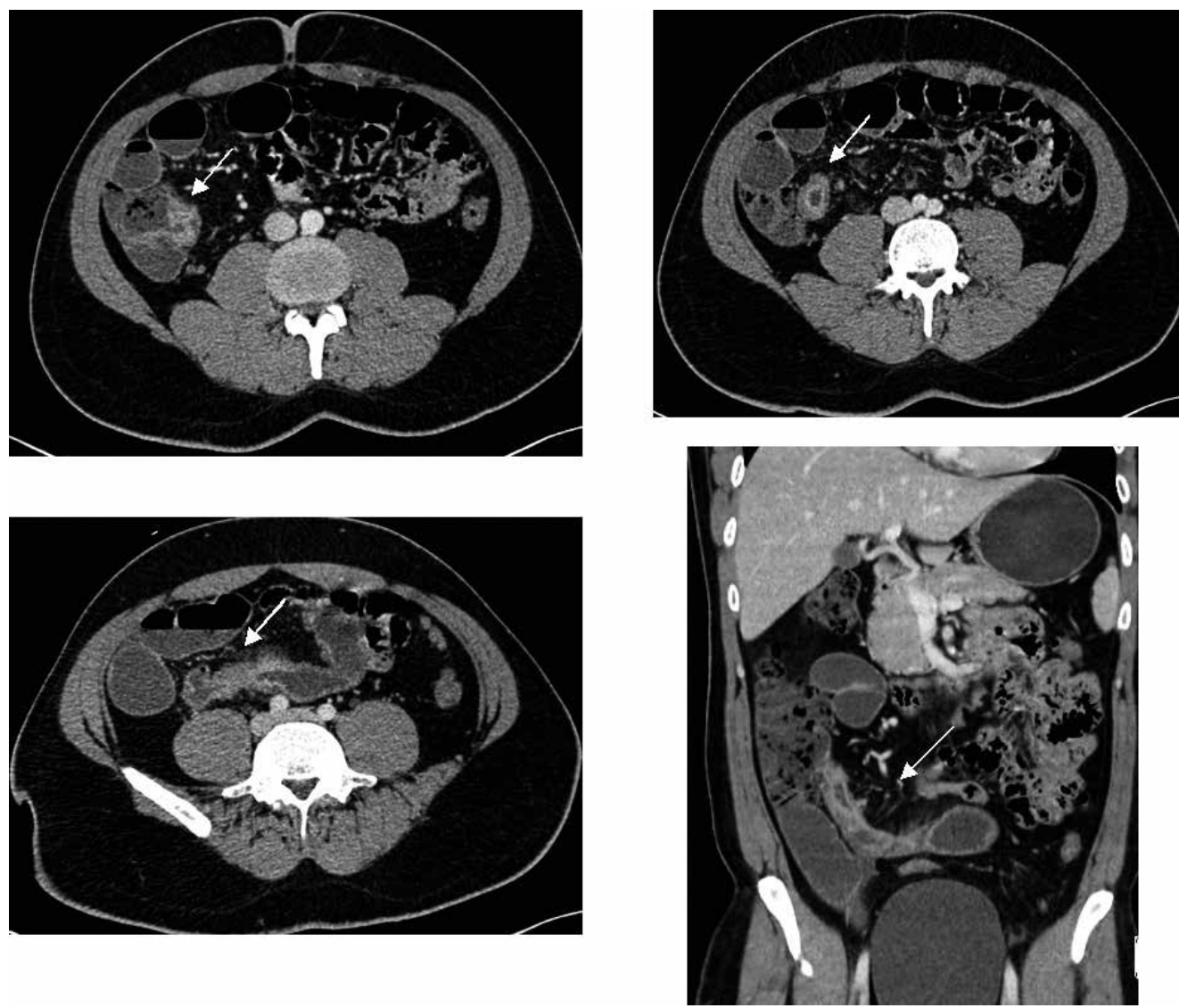

Figura 10. Diverticulitis del íleon. Imágenes en el plano axial y reconstrucciones en el plano coronal. Se observa engrosamiento parietal difuso del íleon distal, con divertículos ileales distales uno de ellos presenta cambios inflamatorios, asociado a aumento de atenuación de la grasa regional (flechas blancas).

de la válvula ileocecal ${ }^{29}$. Generalmente asintomáticos, la mayoría de los casos, particularmente en adultos, son descubiertos de manera incidental durante una exploración quirúrgica abdominal para la evaluación de patología no relacionada. Menos comúnmente son identificados de manera incidental en estudios por imágenes. La inflamación del divertículo ocurre aproximadamente en el $5 \%$ del total de los pacientes portadores (Figura 11).

\section{Divertículos Colónicos}

Los divertículos colónicos son una patología frecuente en población occidental, aumentando su prevalencia a mayor edad ${ }^{30}$. Los más comúnmente encontrados son los pseudodiverticulos, usualmente en el colon izquierdo, en especial en el sigmoides, pero pueden encontrarse en otras ubicaciones menos frecuentes. La prevalencia de divertículos colónicos es alrededor de $20 \%$ a los 40 años y $60 \%$ a los 60 años $^{2,30}$. Existen casos menos frecuentes 

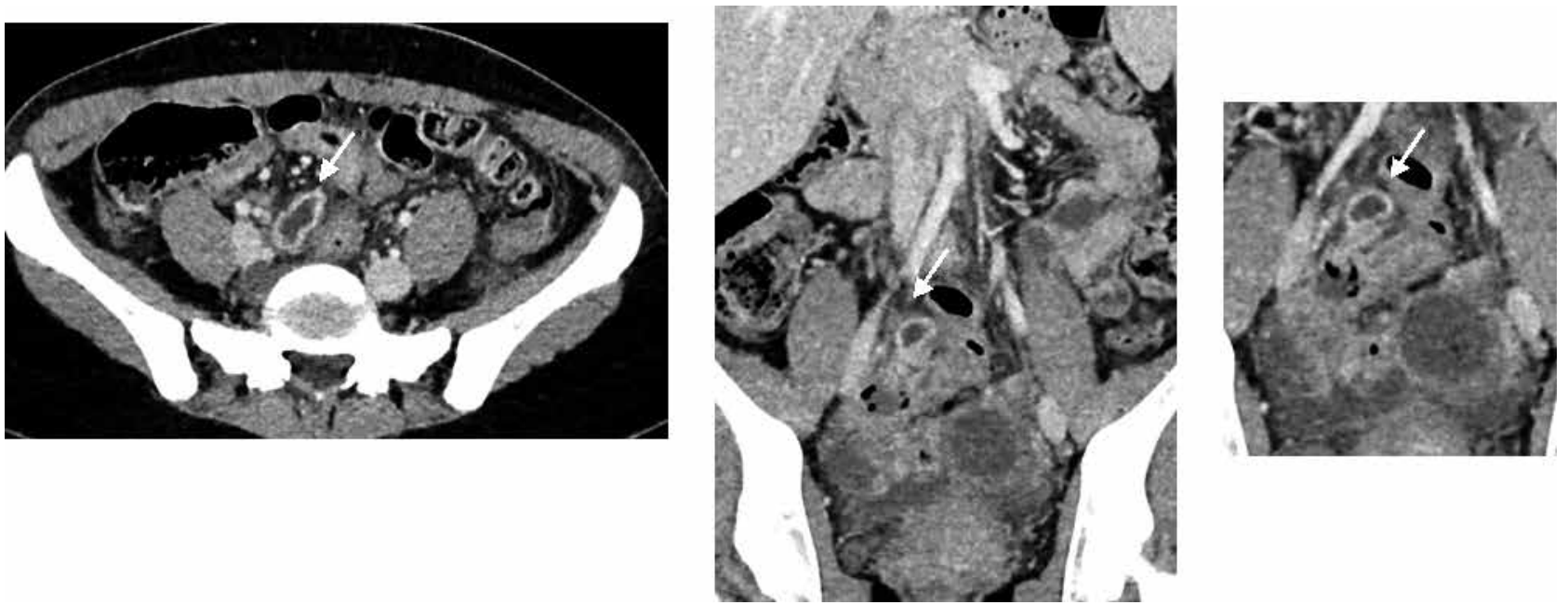

Figura 11. Diverticulitis de Meckel. Imágenes tomografía computada de abdomen con contraste que demuestran cambios inflamatorios en relación a divertículo de Meckel (flechas blancas), compatibles con diverticulitis.

como los divertículos del colon derecho, los que suelen ser divertículos verdaderos que comprometen todas sus capas. Se han descrito alguna presentaciones atípicas como divertículos gigantes ${ }^{31}$, divertículos en hernias que contienen colon o divertículos que son foco de sangrado digestivo ${ }^{1,2,30}$ (Figuras 12, 1314 y 15).

\section{Divertículos apendiculares}

Los divertículos en apéndice son muy poco frecuentes, con una prevalencia de $0,004-2,1 \%$ en estudio histológicos de piezas quirúrgicas ${ }^{32}$. Cuando se complican con diverticulitis, se presenta con dolor abdominal intermitente e insidioso localizado en fosa ilíaca derecha ${ }^{33}$.
Su diagnóstico pre-quirúrgico es difícil tanto en clínica como imágenes. El tratamiento de elección es quirúrgico, debido a su asociación con neoplasias y alto riesgo de perforación ${ }^{32,33,34}$ (Figura 16).

\section{Conclusión}

Los divertículos colónicos son frecuentes, pero existen múltiples otras localizaciones de los divertículos en el tracto gastro intestinal, menos frecuentes. El radiólogo debe estar familiarizado con las diferentes ubicaciones de los divertículos en el tracto digestivo lo que permitirá un mejor diagnóstico, tanto de los divertículos como de sus complicaciones.
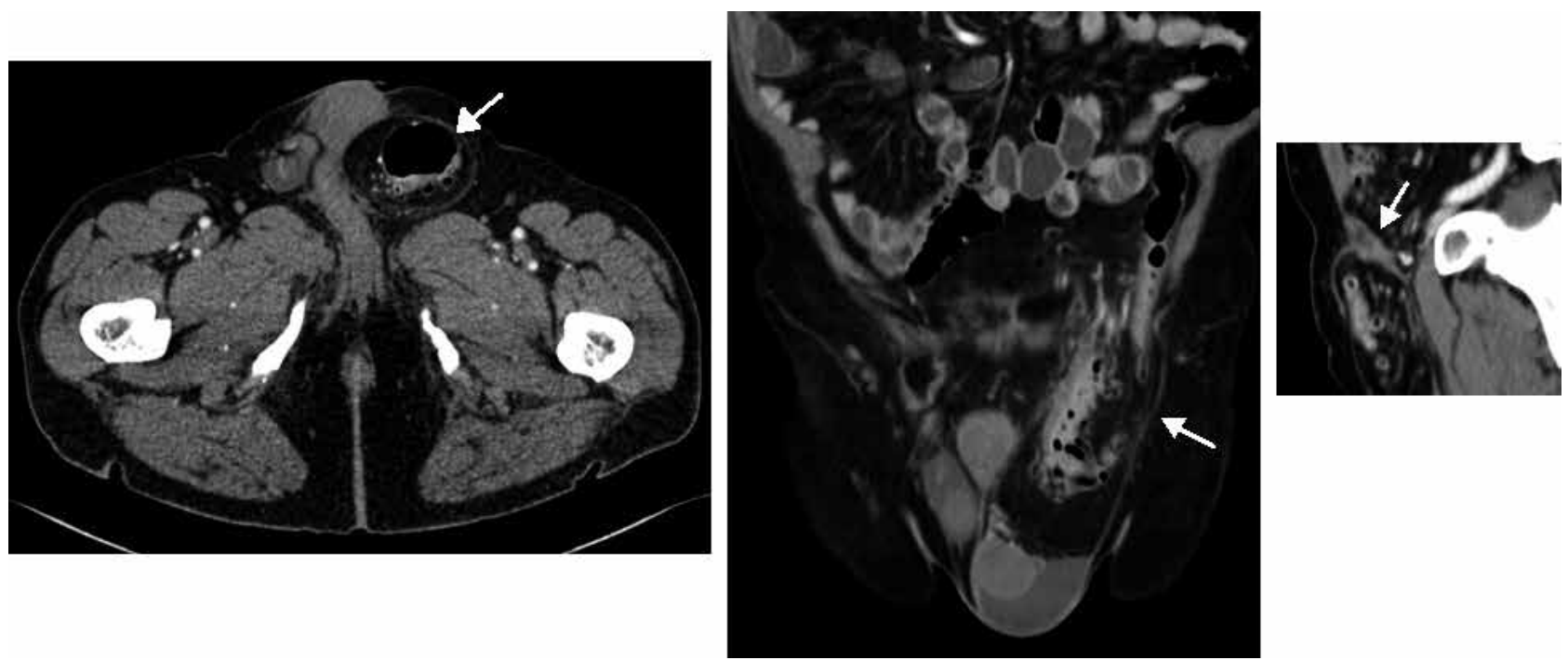

Figura 12. Divertículos en colon sigmoides en hernia inguinal izquierda. Imágenes de tomografía computada axiales, reconstrucciones en el plano coronal y sagital. Se muestra una hernia inguinal con asa de sigmoides con múltiples divertículos, sin signos de complicación (flechas blancas). 

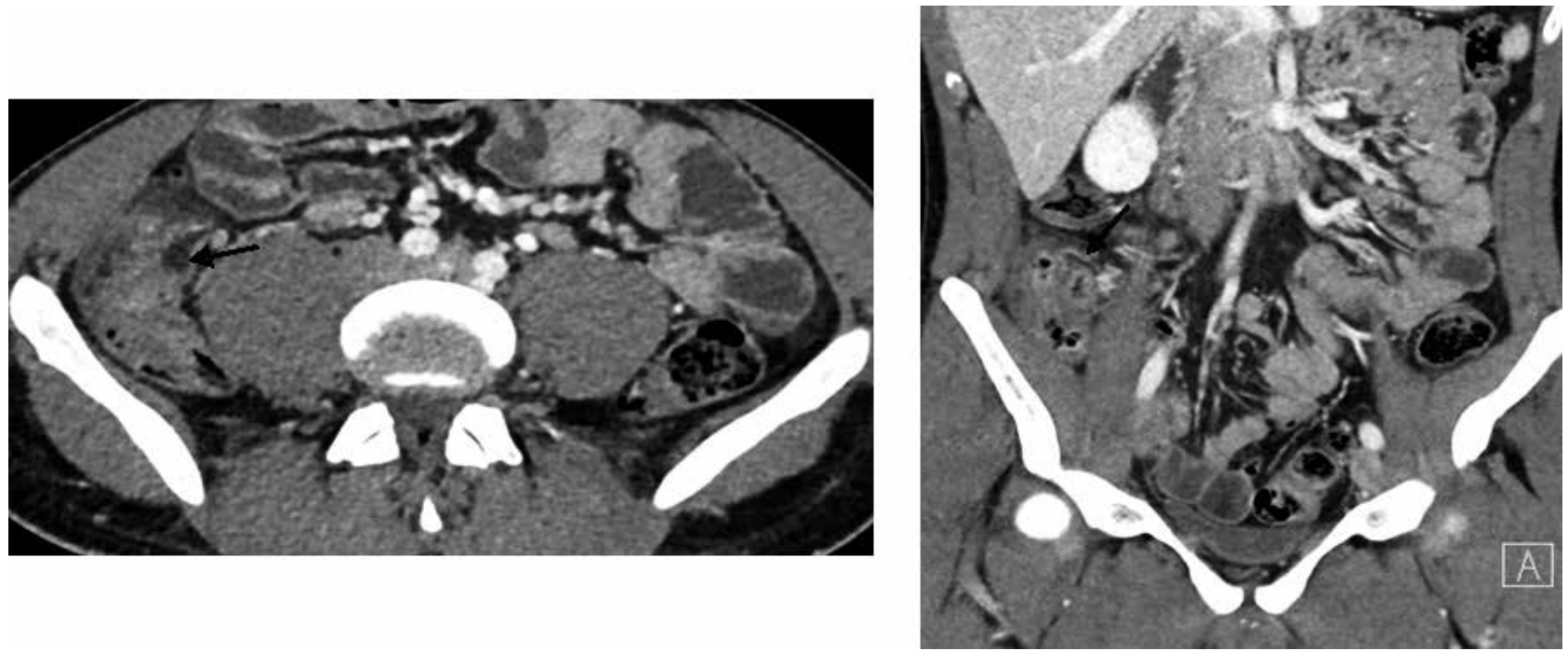

Figura 13. Diverticulitis en colon ascendente. Imágenes de Tomografía computada de abdomen con contraste endovenoso, que demuestra divertículos en colon ascendente con cambios inflamatorios, compatible con diverticulitis aguda (flecha negra).
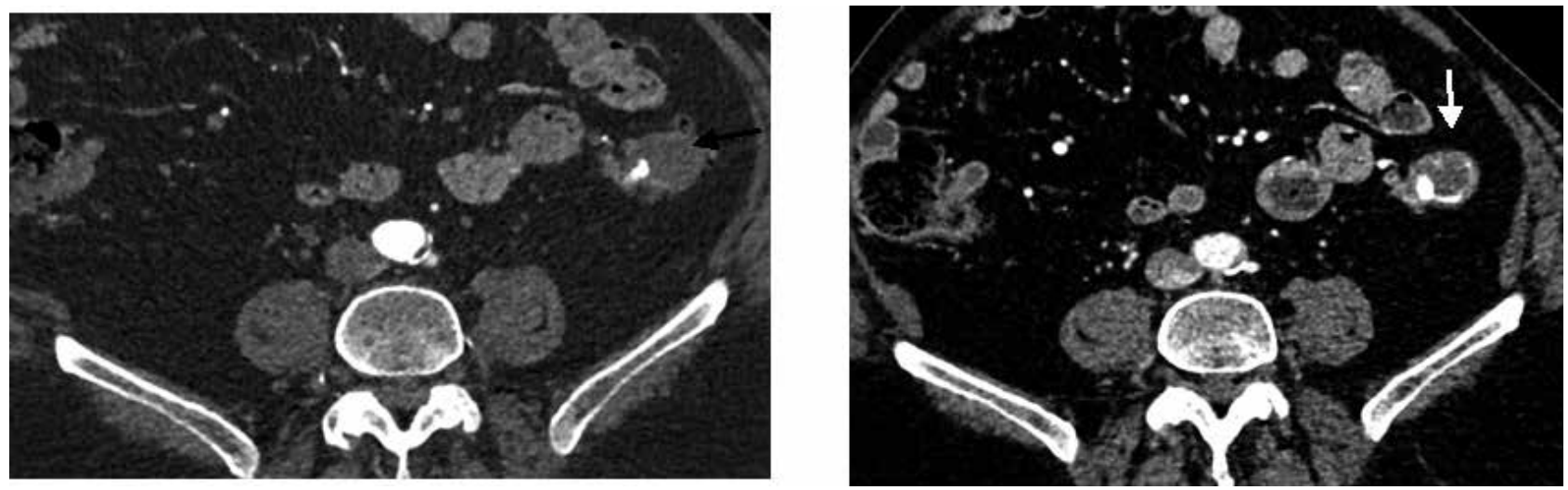

Figura 14. Divertículo hemorrágico en colon descendente. Imágenes de Angiografía por tomografía computada de abdomen en las que se observa divertículos en colon descendente con signos de sangrado activo en relación a un divertículo en el tercio medio del colon descendente. Se evidencia abundante extravasación de contraste al lumen colónico tanto en fase arterial (flecha negra) como venosa (flecha blanca), sin signos de perforación.
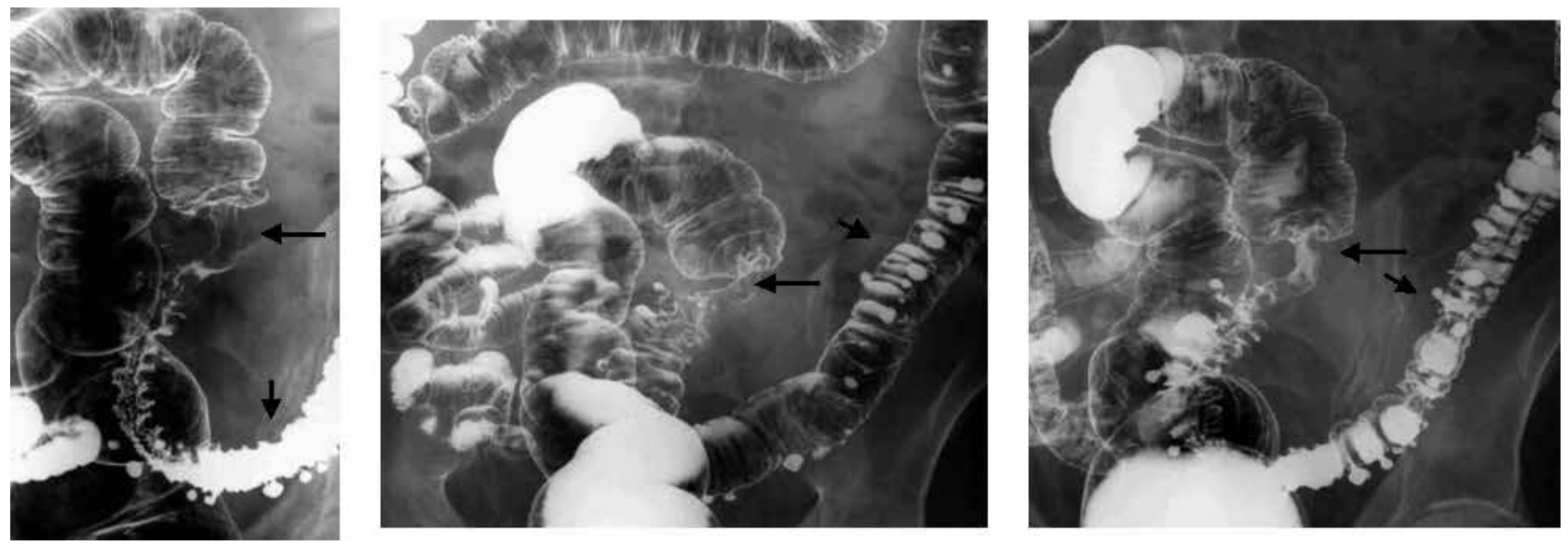

Figura 15. Divertículos colónicos y signos de neoplasia colónica. Imágenes de enema baritado que evidencian múltiples divertículos colónicos (flechas negras) asociado al clásico signo de coronta de manzana (flechas negras), sugerente de neoplasia. 

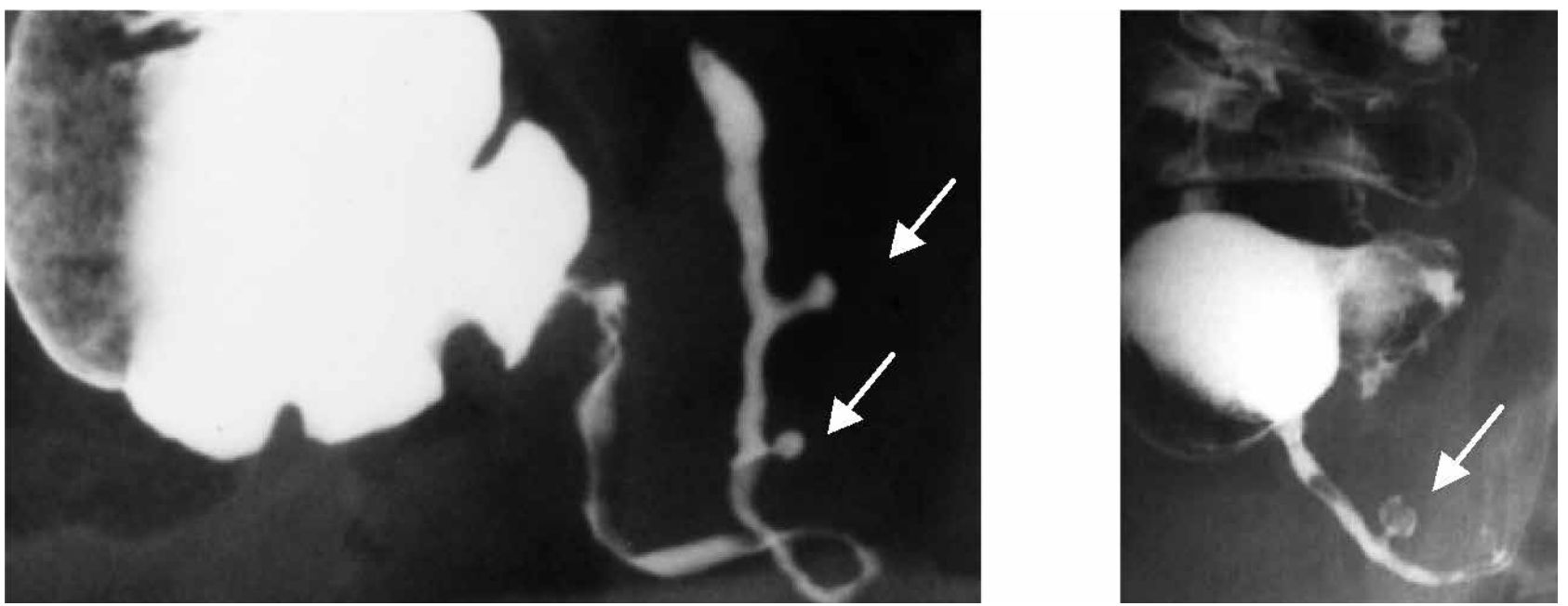

Figura 16. Apéndice con divertículos. Imágenes de Enema con contraste en la que se observan salientes de perfil, compatible con divertículos apendiculares, sin signos de complicación (flechas blancas).

\section{Referencias}

1. Avunduk C. Manual of Gastroenterology, Diagnosis and Therapy. In Lippincott Williams \& Wilkins; 2008.

2. Horton KM, Corl FM, Fishman EK. CT Evaluation of the Colon: Inflammatory Disease. RadioGraphics. 2000 Mar; 20(2): 399-418.

3. Cassivi SD, Deschamps C, Nichols FC, Allen MS, Pairolero PC. Diverticula of the Esophagus. Surg Clin North Am. 2005 Jun; 85(3): 495-503.

4. Carucci LR, Turner MA. Dysphagia Revisited: Common and Unusual Causes. RadioGraphics. 2015 Jan; 35(1): 105-122.

5. Jenkinson EL. Diverticula of the Esophagus. Radiology. 1930 May; 14(5): 508-513.

6. Deschamps C, Trastek U. Esophageal diverticula. In: LoCicero J, Ponn R, editors. General Thoracic Surgery. 5a. Philadelphia: Lippincott Williams \& Wilkins 2000: p. 1839-1849.

7. Coviane E. Divertículo de Zenker. Enciclopedia médica americana. Cirugía Digestiva. 2007.

8. Khan N, Ismail F, Van de Werke IEAA, MMed Rad $M$, Van de Werke IEAA. Oesophageal pouches and diverticula: A pictorial review. South African J Surg. 2012 Aug 2; 50(3): 71-75.

9. Siddiq MA. Pharyngeal pouch (Zenker's diverticulum). Postgrad Med J. 2001 Aug 1; 77(910): 506-511.

10. Verdonck J, Morton RP. Systematic review on treatment of Zenker's diverticulum. Eur Arch Oto-Rhino-Laryngology. 2015 Nov 7; 272(11): 3095-3107.

11. Kwak JY, Kim E-K. Sonographic findings of Zenker diverticula. J Ultrasound Med. 2006 May; 25(5): 639-642.

12. Mercer D, Blachar A, Khafif A, Weiss J, Kessler A. Realtime Sonography of Killian-Jamieson Diverticulum and Its Differentiation From Thyroid Nodules. J Ultrasound Med. 2005 Apr; 24(4): 557-560.

13. Herbella FAM, Patti MG. Modern pathophysiology and treatment of esophageal diverticula. Langenbeck's Arch Surg. 2012 Jan 2; 397(1): 29-35.

14. Michael H, Fisher RS. Treatment of Epiphrenic and
Mid-esophageal Diverticula. Curr Treat Options Gastroenterol. 2004 Feb; 7(1): 41-52.

15. Rashid F, Aber A, Iftikhar SY. A review on gastric diverticulum. World J Emerg Surg. 2012; 7(1): 1.

16. Mohan $P$, Ananthavadivelu M, Venkataraman J. Gastric diverticulum. Can Med Assoc J. 2010 Mar 23; 182(5): E226-E226.

17. Schramm D, Bach AG, Zipprich A, Surov A. Imaging Findings of Gastric Diverticula. Sci World J. 2014; 1-5.

18. Ferreira-Aparicio FE, Gutiérrez-Vega R, Gálvez-Molina Y, Ontiveros-Nevares P, Athie-Gútierrez C, MontalvoJavé EE. Diverticular Disease of the Small Bowel. Case Rep Gastroenterol. 2012; 6(3): 668-676.

19. Lappas JC, Maglinte DD, Kopecky KK, Cockerill EM, Lehman GA. Diverticular disease: imaging with postdouble-contrast sigmoid flush. Radiology. $1988 \mathrm{Jul}$; 168(1): 35-37.

20. Akhrass R, Yaffe MB, Fischer C, Ponsky J, Shuck JM. Small-bowel diverticulosis: perceptions and reality. $\mathrm{J}$ Am Coll Surg. 1997 Apr; 184(4): 383-388.

21. De Peuter B, Box I, Vanheste R, Dymarkowski S. Smallbowel diverticulosis:imaging findings and review of three cases. Gastroenterol Res Pract. 2009: 549-853.

22. Leivonen MK, Halttunen JA, Kivilaakso EO. Duodenal diverticulum at endoscopic retrograde cholangiopancreatography, analysis of 123 patients. Hepatogastroenterology. 1996; 43(10): 961-966.

23. Fintelmann F, Levine MS, Rubesin SE. Jejunal Diverticulosis: Findings on CT in 28 Patients. Am J Roentgenol. 2008 May; 190(5): 1286-1290.

24. Koch AD, Schoon EJ. Extensive jejunal diverticulosis in a family, a matter of inheritance? Neth J Med. 2007 Apr; 65(4): 154-155.

25. Palder SB, Frey CB. Jejunal diverticulosis. Arch Surg. 1988 Jul; 123(7): 889-894.

26. Bittle MM, Gunn ML, Gross JA, Rohrmann CA. Imaging of Duodenal Diverticula and Their Complications. Curr Probl Diagn Radiol. 2012 Jan; 41(1): 20-29.

27. Yoon YS, Park IJ, Lee KH, Kim HC, Yu CS, Kim JC. 
Should small bowel diverticula be removed?. Korean J Gastroenterol. 2004 Nov; 44(5): 275-279.

28. Sagar J, Kumar V, Shah DK. Meckel's diverticulum: a systematic review. J R Soc Med. 2006 Oct; 99(10): 501-505.

29. Zani A, Eaton S, Rees CM, Pierro A. Incidentally detected Meckel diverticulum: to resect or not to resect? Ann Surg. 2008 Feb; 247(2): 276-281.

30. Snyder MJ. Imaging of Colonic Diverticular Disease. Clin Colon Rectal Surg. 2004 Aug; 17(3): 155-162.

31. Thomas S, Peel RL, Evans LE, Haarer KA. Giant CoIonic Diverticulum. RadioGraphics. 2006 Nov; 26(6): 1869-1872.
32. Altieri ML, Piozzi GN, Salvatori P, Mirra M, Piccolo G, Olivari N. Appendiceal diverticulitis, a rare relevant pathology: Presentation of a case report and review of the literature. Int J Surg Case Rep. 2017; 33: 31-34.

33. Osada H, Ohno H, Saiga K, Watanabe W, Okada T, Honda N. Appendiceal diverticulitis: multidetector CT features. Jpn J Radiol. 2012 Apr 22; 30(3): 242-248.

34. Schiappacasse G, Whittle C, Leiter F, Cortes C, Gallardo A, Cavalla C. Hallazgos imagenológicos en diverticulosis y diverticulitis apendicular. Serie de casos. Acta Gastroenterol Latinoam. 2017; 47(3): 205-210. 